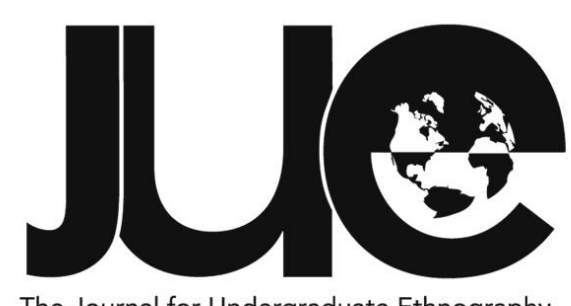

\title{
Pequot Warriors Combating Paper Genocide: How the Eastern Pequot Tribal Nation Uses Education to Resist Cultural Erasure
}

\author{
Lan-Húóng Nguyễn
}

Connecticut College, LHNguyen2019@gmail.com

Research Collaborators: Eastern Pequot Tribal Nation

\section{ABSTRACT}

This paper analyzes the southeastern Connecticut Eastern Pequot Tribal Nation's battle with cultural erasure and resistance through education. Indigenous education programs are gradual yet the most effective method of resisting Western cultural erasure from the United States government, because they peacefully invite both Natives and non-Natives to learn about Native American history outside of European colonizer textbooks. The Tribe battles the erasure that can result from external parties' ability to grant state or federal titles recognizing tribal authority (known as recognition titles) to determine who receives the powerful stamp of Indigeneity and the right to selfgovern. My case study focuses on the Eastern Pequots Archaeology Field School project in collaboration with University of Massachusetts, Boston. I evaluate how the Eastern Pequots use a collaborative archaeology education program with their Tribal members and nonNative individuals to resist erasure by decolonizing Western pedagogy. The Field School has gathered over 99,000 artifacts over 15 seasons that dismantle common misconceptions of how Native Americans lived during the beginning of the United States' history and redefine modern beliefs about how Natives survived European colonization. The Field School contributes to expanding brief descriptions of Native history into a more complicated and dynamic story that elaborates on Native struggle, survival and resistance.

Keywords: Tribal Nations, land-based education, decolonization, archaeology 
T he colonial history of the United States between the seventeenth and nineteenth centuries is complex, but American textbooks reduce its dark and morbid history in order to erase the true interactions between colonists and Native Americans. Simplifying these interactions misrepresents the deadly impact of European colonialism on the east coast during the 17th century. As a result, the United States' origins are retold to favor the colonists by justifying their horrific actions against Native Americans. Also called "paper genocide," this is one of many strategic methods that wipes out Native American identity from the North American population, thus delegitimizing Native existence in the United States today. Paper genocide refers to the United States government actively writing Native Americans out of history while denying support for the future of Tribal Nations (Hardin 2015). Repositioning the contemporary education system to center on Native Americans gives the Native community the agency to incorporate their perspectives into a Eurocentric and Western dominated society that endlessly tries to silence this community. Gradual, Indigenous education programs are arguably the most effective method of resisting Western cultural erasure from the government because this method peacefully invites Natives and non-Natives to learn about Native American history outside of the context of European colonizer textbooks.

In this paper, I analyze the southeastern Connecticut Eastern Pequot Tribal Nation's battle with cultural erasure and resistance through education (Figure 1 shows the location of this nation). The Tribe battles erasure by external parties that can grant recognition titles (state and/or federal) to determine who receives this powerful stamp of Indigeneity, which legitimizes the Tribe in the eyes of the state and gives it the right to self-govern. I evaluate how the Eastern Pequots use a collaborative archaeology education program with their Tribal members and non-Native individuals and a decolonizing pedagogy to resist erasure. My main case study focuses on the Eastern Pequots Archaeology Field School project in collaboration with University of Massachusetts, Boston, led by Professor Stephen Silliman. The vital information found throughout each excavation plays a role of legitimizing the Eastern Pequot identity. Throughout the summer of 2018 Field School, I used a multi-purpose approach to collect data: 1) I conducted participant observation to assess the collaborative archaeology component, 2) I conducted 12 semi-structured interviews with Eastern Pequot members and Silliman to understand their perspectives on the history and benefits of the program, and 3) I assessed entry and exit surveys with 12 Non-Native students to evaluate their perceptions of Indigeneity within the Field School. Throughout the coding process, I identified specific patterns, focusing on various educational outlets such as the Field School, the Mashantucket Museum, and any programs that the Eastern Pequot holds. Lastly, I evaluated the educational impact on the Eastern Pequot identity.

Both my independent research and the Field School's research combats Native American invisibility by teaching the broader non-Native community in Southeastern Connecticut, a large group of privileged individuals who unknowingly walk on historic Pequot territory, that modern cultural genocide of Native American communities is ongoing in the United States today. Additionally, both research methods demonstrate that the Eastern Pequot Tribal Nation is a strong sovereign Nation actively seeking methods to re-indigenize the Western and Euro-centric education system. The Field School makes artifacts and primary sources accessible to students from University of Massachusetts, Boston and Connecticut College and that contributes to the growing academic literature specifically focused on the Eastern Pequot Tribal Nation. Eastern Pequot members witness how the Field School has uncovered over 99,000 artifacts over 15 seasons, which literally and figuratively grounds 


\section{New England}

Connecticut, Maine, Massachusetts, New Hampshire, Rhode Island, and Vermont
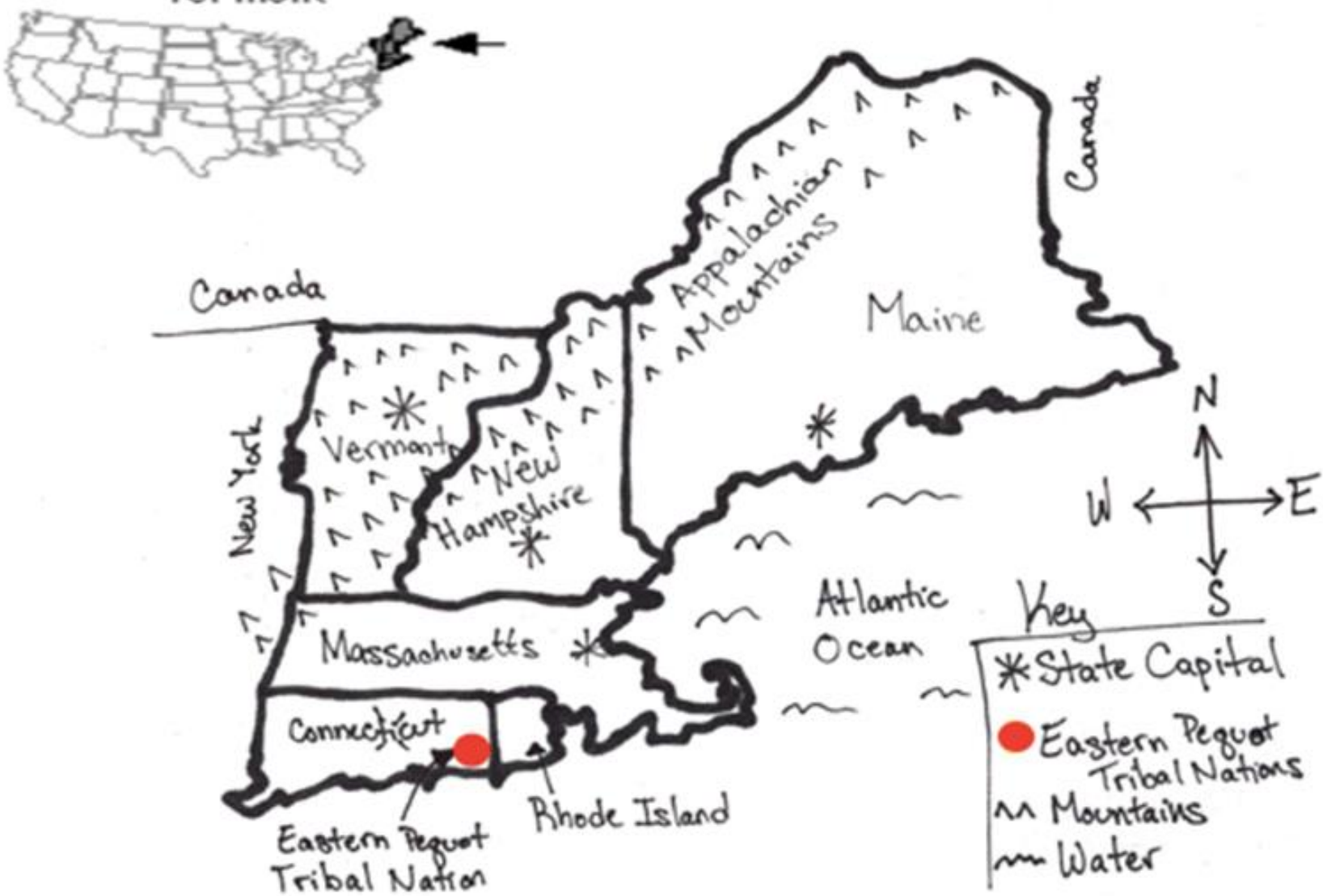

Figure 1. Map of New England and the Eastern Pequot Tribal Nation reservation

the Tribal members to their long-standing reservation. Some of these artifacts include: arrowheads, musket bullets, dining utensils, and jackfield pottery. The artifacts expand the limited description of the beginning of Native American history in the United States' colonialism into a more complicated and dynamic narrative to elaborate upon Native survival and resistance. These items are proof that the Eastern Pequots' ancestors lived, survived, and thrived on the same land that European colonizers and current Tribal members walk on today.

Throughout the course of three years, I built strong relationships with the Eastern Pequots that stemmed from another collaborative community project with my home institution, Connecticut College. During this time, many Eastern Pequots shared with me their backgrounds and emotions about the federal recognition process in 2005 that fractured their nation. As a shared experience among the Eastern Pequots, I focus on recognition titles as a form of cultural erasure to assist the Eastern Pequots in increasing awareness of how the US government and the Bureau of Indian Affairs invalidate Native Americans' ancestral history and stripping them of their right to govern. The Eastern Pequot Tribal members were hosts, land-based educators, and editors throughout the production of this paper. Tribal members whom I had the pleasure of interviewing and Tribal Council members shared their ideas of how they wanted their Tribal Nation to be represented from an outsider's perspective. The relationship we shared makes an explicit contribution to a growing trend of researchers collaborating with Indigenous communities on academic work. 
Methods of Modern Cultural

\section{Erasure: The Recognition of Tribal Nations}

While recognition status serves to support many Native communities, it can also be used as a weapon against Native Americans. One modern form of cultural erasure is the Tribal Nation's recognition titles. Commonly referenced as "paper genocide" among Native members, federal and state recognition titles determine Native Americans' significance to United States history and can refute their identity (Personal Communication: Mashantucket Pequot Member: October 8, 2017). Even in the 21st century, this serves as a reminder that Native Americans are still not welcomed in the United States or are given full autonomy.

The Significance of Federal Recognition Titles

The Eastern Pequot Tribal Nation has continually been slaughtered and forced off of their land by intrusive colonizers, which was exacerbated when the US government denied the Tribes' federal recognition in 2005 (Ferguson 1996). Federal recognition acknowledges a government-to-government relationship between Tribes and the United States (US Congress and the Bureau of Indian Affairs (BIA)) that allows for tribal sovereignty (NCSL website). The BIA was created in 1824 under the Department of War (Charles 1999). Later, it was moved to the Department of Interior in 1849, so the US government could oversee public land under one government agency (Charles 1999). There are over one hundred BIA field agencies and special officers stationed directly on Native reservations that serve federally recognized Tribes (Charles 1999, 26). Federally recognized Tribes have stronger and more direct communication with the United States government than their nonrecognized counterparts, so federally recognized Tribes can use this advantage to raise awareness of any social issues they face while the United States government directly oversees and controls Native populations. This relationship can be beneficial as federally recognized Tribes have agency while still being respected by the United States government with limited involvement.

To gain federal recognition, the United States government requires Native Tribes to prove their Native American ancestry through seven criteria (Table 1). One of the requirements includes that "they've had 'continuous political authority and community' since 1989 and 'an external entity' has identified the group as Indian since 1900" (Bogado 2014, 3). It is necessary to note that an "external" party is used to define if a Tribe has been "Indian" long enough to receive this title (Bogado 2014, 3), so it offers colonizers the power to maintain or erase a group of people from history. Tribes

Table 1. Seven requirements to be a federally-recognized Native American Tribe

1 The petitioner has been identified as a Native American entity since 1900s.

2 A predominant portion of the petitioning group comprises a distinct community.

3 The petitioner has maintained political influence or authority over its members.

$4 \quad$ The group has governing documents which include its membership criteria.

The petitioner's membership consists of individuals who descend from a historical Native

5 American Tribe or from historical Native American Tribes which combined and functioned as a single autonomous political entity.

6 The membership of the petitioning group is composed primarily of persons who are not members of an acknowledged North American Native Tribe.

$7 \quad$ Neither the petitioner not its members are the subject of congressional legislation that has expressly terminated or forbidden the federal relationship. 
Table 2. Tribal Nation Recognition Titles Benefits Summary (source: author)

\begin{tabular}{|c|c|}
\hline Federal & State \\
\hline $\begin{array}{l}\text { Acknowledges direct relationship between Tribal } \\
\text { government to the United States government }\end{array}$ & $\begin{array}{l}\text { Acknowledges Tribal status within state govern- } \\
\text { ment, but not at federal level }\end{array}$ \\
\hline $\begin{array}{l}\text { Federal government acknowledges a Tribal Na- } \\
\text { tion's historical and cultural contributions to the } \\
\text { United States' history }\end{array}$ & $\begin{array}{l}\text { Federal government does not believe there is } \\
\text { enough tangible evidence that proves a Tribal Na- } \\
\text { tion's historical and cultural contributions to the } \\
\text { United States' history }\end{array}$ \\
\hline $\begin{array}{l}\text { Possess certain inherent rights to self-government } \\
\text { (i.e. tribal sovereignty) without or limited influence } \\
\text { from United States Congress }\end{array}$ & $\begin{array}{l}\text { Can have limited Tribal participation in state com- } \\
\text { missions that typically make policy decisions that } \\
\text { affect Native Americans }\end{array}$ \\
\hline $\begin{array}{l}\text { Guaranteed to receive federal benefits, funding, } \\
\text { services, and protection that provide funds for } \\
\text { health care, education programs, housing, and } \\
\text { building casinos }\end{array}$ & $\begin{array}{l}\text { Can qualify for Federal and State support but there } \\
\text { is no guarantee of funding from state or federal } \\
\text { government }\end{array}$ \\
\hline $\begin{array}{l}\text { Allows Native communities to sue federal court for } \\
\text { illegal land encroachment by state government } \\
\text { and individuals }\end{array}$ & $\begin{array}{l}\text { Does not allow Native communities to sue federal } \\
\text { court, state government, or individuals for any ille- } \\
\text { gal land encroachment }\end{array}$ \\
\hline
\end{tabular}

with federal recognition have the right to govern themselves without any (or with very limited) influence from the United States Congress (NCSL website). It also allows Tribes to benefit from government programs that provide funding for health care, education programs, housing, and building casinos (Starn 2011). Through collaboration with the Indian Self-Determination Act and Education Assistance Act and the BIA, federally recognized Tribes can contact federal agencies to plan programs and functions that benefit Natives (Charles 1999, 28). One of the most significant benefits of being a federally recognized Tribe is that it permits Native communities to sue the federal court for land which was taken illegally by the state government and individuals (Starn 2011).

In contrast, state recognition acknowledges a Tribe's status, but it does not guarantee additional help or funding from the state or federal government (NCSL website). The US government's strict criteria mean that it is difficult for Native communities to obtain enough tangible historic resources to prove their ancestry or community. By granting the approval or denial of federal recognition status, the United States government and BIA are the gatekeepers to Tribal Nations' ability to revive and sustain their own identity. Additionally, the state government can manipulate the Tribal Nation's land if they choose to without being federally regulated or stopped (Starn 2011), so the state-recognized Native Tribes cannot sue the state government for intruding on their land. As a result, state-recognized Tribes such as the Eastern Pequots do not have full agency over their own property.

Denying or removing recognition titles contributes to ongoing paper genocide. The United States Congress and BIA determines which Indigenous groups receive the powerful stamp of Indigeneity and the right to selfgovern. Which groups are Native American enough to receive this federal title and which agencies determine this? According to anthropologist Audra Simpson, in her work Mohawk Interruptus (2014), sovereign nations may exist within another nation without being negated while recognition can exist within a framework of multicultural politics (Greymorning 2014, 445). The ability of tribal nations to self-govern as sovereign nations is self-determined without an external party; 
however, the United States continues to be an overbearing presence over these Tribal Nations because the United States assigns recognition. The power structures between the Tribal Nations and the United States government contributes to the constant "debate, doubt, and revision" of one's Indigenous identity that leads to a never-ending battle between "belonging and exclusion" (Starn 2011, 186).

\section{Eastern Pequot Recognition Titles: Paper Genocide}

Since the 1970s, the Eastern Pequot Tribal Nation, also known as the Paucatuck Eastern Pequots, encountered many obstacles when they were filing for their federal acknowledgement. In 1978, Eastern Pequots began navigating their federal recognition process (Figure 2). They filed a letter of intent to petition the United States Department of the Interior (DOI) for acknowledgement as a Tribal Nation. For many years, the Eastern Pequot Tribal Council members searched for progenitors to support the seven requirements to be federally recognized. In 2000, the Eastern Pequots received preliminary positive feedback on their federal acknowledgement from the Bureau of Indian Affairs (BIA) after they demonstrated to the United States government their ability to maintain community, political, and cultural practices. During this time, the BIA recommended that the Eastern Pequots and the Paucatuck Eastern Pequots join together as one Tribe during their federal recognition process (McFadden 2000). This suggestion, however, raised many uncertainties about whether the groups consist of two Tribes or different divisions of the same tribe in addition to which group is the true descendent from the original Pequots (McFadden 2000, 2). Although both tribes applied for recognitions separately, they each faced many challenges. In 1990, the bureau stated that the Eastern Pequots "skipped generations in their attempt to show historic links to ancestors" (McFadden 2000, 3). Later in 1994, the bureau stated that the Paucatucks did "not [prove] it was a distinct community since historic times" (McFadden 2000, 3).

Another obstacle the Eastern Pequots faced during their federal recognition process was the local townspeople from New London,
Uncasville, and North Stonington's misunderstanding of what a recognition title provides for Tribal Nations. Due to the two largest and most successful federally recognized Native casinos being locally owned in southeastern Connecticut by the Mashantucket Pequots and Mohegans, nonNatives immediately assume that federal recognition is "synonymous with casinos" (Personal communication with N. Gambrell: July 15, 2018). When the Eastern Pequots and the Paucatucks first announced their federal recognition process, news outlets questioned the Tribes if they planned to build casinos in the area (McFadden 2000). In 2000, the local townspeople were concerned with the Eastern Pequots' and the Paucatucks' lack of response on building a casino (McFadden 2000). When asked again in 2002, Tribal members did not believe they were capable of obtaining a casino (Groark 2002). In fact, James A. Cunha Jr., the Paucatuck Eastern Chief at the time, stated, “There's no land. There's no casino. There's nothing. There are other hurdles we have to clear before we get to that point" (Groark 2002). Although the two nearby Native casinos bring in millions of dollars' worth of revenue each month to the southeastern Connecticut region, the biggest concerns are the large number of cars brought into the area and the taxed local services (Groark 2002). Officials from the three towns surrounding the Mashantucket Pequots' Foxwoods Resort Casino argued that adding one or two more casinos would only worsen the situation in the area. As a result, New London, Uncasville, and North Stonington invested over $\$ 500,000$ to monitor the two Tribes' recognition petitions (Groark 2002).

After being pressured by the Connecticut attorney general Richard Blumenthal and representatives of three towns, via Freedom of Information Act lawsuits, the assistant secretary for Indian affairs granted the Eastern Pequots federal recognition in September of 2002. At this time, the DOI acknowledged the tribe as one of the oldest reservations in the United States with an "unbroken history" (Silliman and Sebastian Dring 2008). Within three months, the Eastern Pequots' achievement of federal acknowledgment faded because some public officials, local towns, and other politically motivated parties influenced the decision to 
retract the original acknowledgment. For more than two years, the Eastern Pequots were held in appeal.

In May 2005, the Internal Board of Indian Appeals communicated their final decision to the assistant secretary for Indian affairs. Later, on October 12, four months after the final acknowledgment was under reconsideration, ironically two days after Columbus Day, the assistant secretary rescinded the Eastern Pequots' original federal determination (Bogado 2014). To combat this, the Eastern Pequots sent a notice of appeal of the final determination in November 2005 to reconsider their decision to decline acknowledgement to the Interior Board of Indian Appeals. In January 2006, the Interior Board of Indian Appeals' response stated that the administrative process of acknowledgement petitions was complete and the Eastern Pequots' reconsidered final determination was effective (Bogado 2014).In 2015, Connecticut's politicians, including Senator Richard Blumenthal, praised the BIA's decision to revise its rule to block additional Connecticut Tribes from all second chances of winning federal recognition (Redelat 2015); thus, it has become harder for the Eastern Pequots to fight for their rightfully deserved recognition title.

\section{As of 2016, the state of Connecticut}

recognizes that the Eastern Pequots are a selfgoverning entity that possess power and duties over their tribal members and reservations (Constitution of the Eastern Pequot Tribal Nation 2007). Their powers and duties include: 1) the ability to determine tribal membership and residency on reservation land; 2 ) determine the tribal form of government; 3) regulate trade and commerce on the reservation; 4) make contracts; and 5) determine tribal leadership in accordance with tribal practice and usage (Connecticut General Statutes 47-63 2016).

Through their ownership of the most successful Native casinos in the country, both the Mashantucket Pequots and Mohegans prominently mark their economic and social dominance over a territory that nearly masks the Eastern Pequots land reservation (Figure 3). Additionally, the Mashantucket Pequot Museum and Resource Center preserves Pequot history for the education of both the Native and NonNative community. It is a beneficial resource to both Pequot communities because they "share history" before colonialism (Personal communication with J. Silva: September 8, 2018). In contrast, the Eastern Pequots' land is found within the peaceful woods near their cousins' bustling casinos. Each Tribe's reservation is located in various parts of Connecticut that affects how they use their land

\begin{tabular}{|c|c|c|c|c|c|}
\hline $\begin{array}{l}\qquad 1978 \\
\text { Eastern Pequot } \\
\text { begins their Federal } \\
\text { recognition process }\end{array}$ & $\begin{array}{c}\text { 1980-2000 } \\
\text { Eastern Pequot Tribal } \\
\text { Council searched for } \\
\text { progenitors }\end{array}$ & $\begin{array}{l}\qquad 2000 \\
\text { Eastern Pequot } \\
\text { receive positive } \\
\text { preliminary positive } \\
\text { feedback on their } \\
\text { Federal } \\
\text { acknowledgement. } \\
\text { BIA recommended } \\
\text { Eastern Pequots and } \\
\text { Paucatucks Eastern } \\
\text { Pequots join together }\end{array}$ & $\begin{array}{l}\quad 2000-2002 \\
\text { Local towns people } \\
\text { of North Stonington, } \\
\text { New London, and } \\
\text { Uncasville became } \\
\text { concerned with the } \\
\text { possibility of building } \\
\text { another Native } \\
\text { casino }\end{array}$ & $\begin{array}{l}2002 \\
\text { Eastern Pequots } \\
\text { receive federal } \\
\text { recognition from } \\
\text { Connecticut } \\
\text { attorney general } \\
\text { Richard } \\
\text { Blumenthal, three } \\
\text { local towns, and } \\
\text { assistant secretary } \\
\text { for Indian affairs }\end{array}$ & $\begin{array}{c}\text { May } 2005 \\
\text { Internal Board of Indian } \\
\text { Appeals returned their } \\
\text { final decision back to the } \\
\text { assistant secretary } \\
\text { rescinded Eastern } \\
\text { Pequot's original federal } \\
\text { determination }\end{array}$ \\
\hline
\end{tabular}

\begin{tabular}{|c|c|c|c|c|}
\hline $\begin{array}{l}\text { October } 2005 \\
\text { Assistant } \\
\text { secretary } \\
\text { rescinded } \\
\text { Eastern Pequot's } \\
\text { original federal } \\
\text { determination }\end{array}$ & $\begin{array}{l}\text { November } 2005 \\
\text { Eastern Pequots } \\
\text { sent a notice of } \\
\text { appeal of final } \\
\text { determination to } \\
\text { reconsider their } \\
\text { decision to decline } \\
\text { acknowledge to the } \\
\text { Interior Board of } \\
\text { Indian Appeals }\end{array}$ & $\begin{array}{c}\text { January } 2006 \\
\text { Interior Board of Indian } \\
\text { Appeals stated that the } \\
\text { administrative process of } \\
\text { acknowledgement } \\
\text { petitions was complete } \\
\text { and the Eastern Pequots' } \\
\text { final determination was } \\
\text { effective }\end{array}$ & $\begin{array}{l}2015 \\
\text { Connecticut's politicians, } \\
\text { including Senator } \\
\text { Blumenthal praised the } \\
\text { BIA's decision to revise } \\
\text { the rule that blocks } \\
\text { additional Connecticut } \\
\text { Tribes from second } \\
\text { chances of winning } \\
\text { federal recognition }\end{array}$ & $\begin{array}{l}2016 \\
\text { Connecticut recognizes } \\
\text { the Eastern Pequots as a } \\
\text { self-governing entity that } \\
\text { possess power and } \\
\text { duties over their Tribal } \\
\text { members and } \\
\text { reservations }\end{array}$ \\
\hline
\end{tabular}

Figure 2. Timeline of Eastern Pequots' federal recognition process 
for social gatherings such as the annual PowWow. "Although they may be economically poor, the Eastern Pequots are culturally rich" in that their history and experiences are more dynamic and complicated than common American history books explain (Personal communication with R. Flores: May 12, 2017). In the small southeastern corner of Connecticut, state recognized Tribes are overshadowed by their federally recognized cousins, so their identities and the social injustices they face are left practically invisible. and non-Native communities alike (Manuelito 2015 , 84). In contrast to protests or sit-ins, education is not an overtly activist or violent action. Instead, it is a strategic method that can make political changes without any damaging political deaths or symbolic arrests. Collaborative archaeology and anthropology projects can encourage mutual dialogue between groups to reposition Native people back into the dominant education curriculum through land-based education (Wildcate, McDonald, Irlbacher-Fox, and Coulthard 2014).

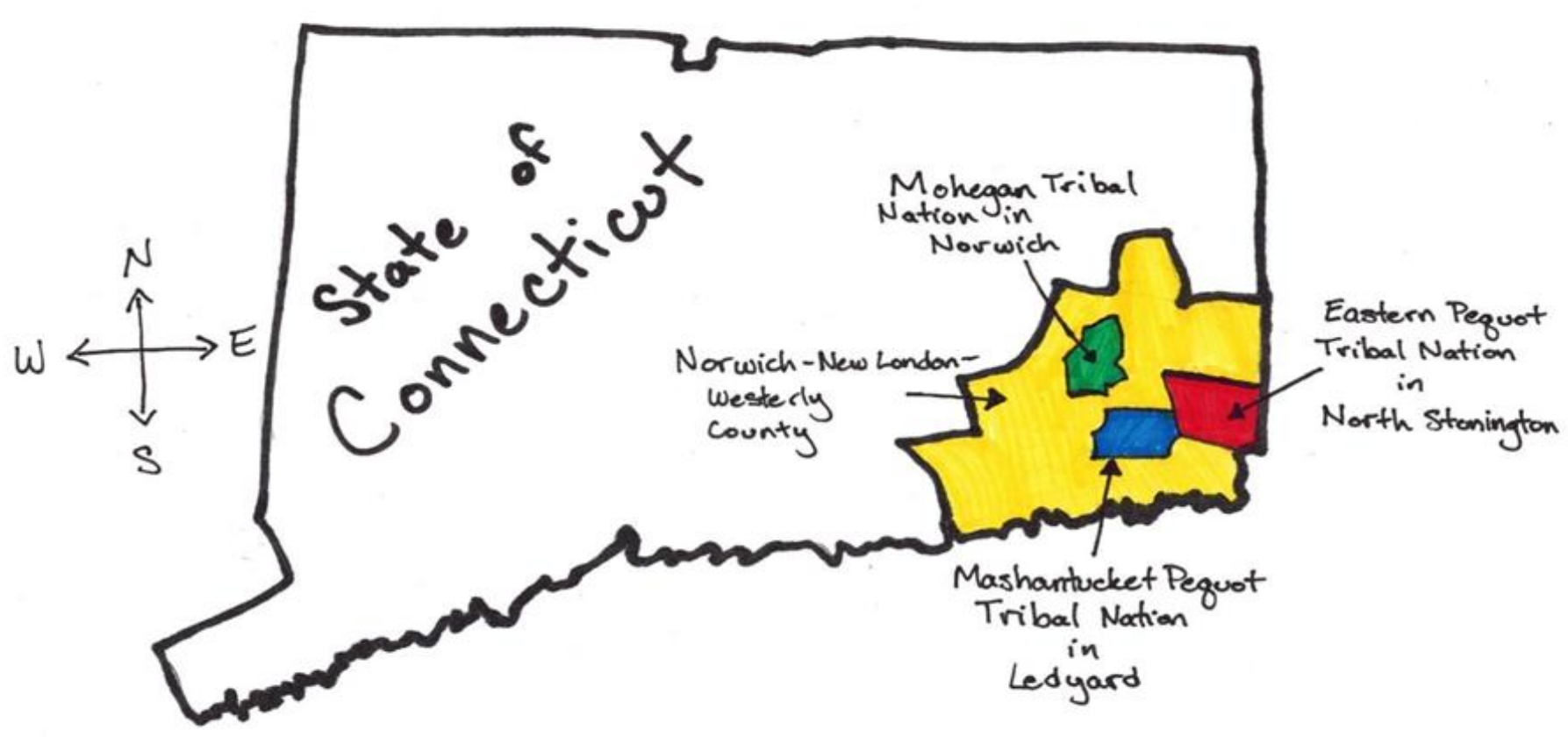

Figure 3. Map of three Southeastern Connecticut Native American Tribal Nations' reservation (Mohegans, Mashantucket Pequots, and Eastern Pequots) (source: author)

\section{Education as a Form of Resistance}

\section{The Role of Archaeology and Anthropology within Indigenous Culture}

Although gradual, Indigenous education programs are an effective method of resisting cultural erasure from the government because they peacefully invite Natives and non-Natives to learn about Native American history outside of the European colonizer textbooks. This is ironic because education in boarding schools was previously used to obliterate Native communities in the United States; however, it has transformed into one method of survival (Manuelito 2005) Dismantling the colonial discourses about Indigenous people strengthens self-determination within Native
Repositioning Native people to the forefront of education curriculums reverses the power structure between them and elite academics according to Julie Kaomea from the University of Hawai'i at Mānoa (Ismail and Cazden 2005). In 1975, the United States government passed the Indian Self-Determination and Education Assistance Act that provided Tribal and community-based schools that were essential to Native survival (Manuelito 2005). It gives Native communities the opportunity to express and practice self-determination as colonized peoples while being active participants in shaping their own future (Manuelito 2005). Five large Tribes - Cherokee, Choctaw, Chickasaw, Creek, and Seminole - credit their cultural revival success to their youth and their ability to have local and Tribal control over education 
systems and community based bilingual programs (Manuelito 2005). Rigid American school systems, state, and federal agencies are large barriers for Native communities to spread their cultural knowledge (Ismail and Cazden 2005).One simple yet unproductive solution many American schools use is to sprinkle Native studies or racial courses into the program to reduce the lack of diversity taught in class. Mary Hermes argues that cultures cannot simply be added to the existing schooling system because it will reduce the culture's significance (Ismail and Cazden 2005). As seen in collaborative archaeology projects, one method is to find the balance between teaching Native American studies to non-Native audience while giving Native Americans their own agency to teach their own history (Gaudry and Lorenz 2018).

Anthropologists' and archaeologists' past relationship with Native Americans can be described as Audre Lorde's maxim "master's tools" to benefit colonialism; however, the current discipline leans on collaboration to dismantle these oppressive power structures (Lorde 1984, 110; Field 1999). Throughout the 1800s, archaeologists used the "Vanishing Red Man Theory" as a scientific justification to collect Native remains off of their reservation for craniology (Ferguson 1996). As a result, Native communities were "dehumanized and objectified ...[to] prove that Native Americans were racially inferior and naturally doomed to extinction" (Ferguson 1996, 65). In addition, this theory contributed to the government's "scientific justification" for relocating Tribes and reservations (Ferguson 1996, 65). Later in the 1900s, the power dynamics between Native communities and archaeologists slowly incorporated equitable practices and laws. Archaeologists use cultural resource management (CRM) as a method to mediate the material culture found in the digs. CRM still threatened Native Tribes because it commodified knowledge produced by archaeologists by moving it into commercial areas and private consulting companies (Ferguson 1996, 65-66). Additionally, many laws were passed to promote more equitable research methods on Native land such as the Antiquities Act of 1906. This specific law was the first to establish that archaeological sites of historic, scientific, and commemorative values should be preserved and managed for future generations. The President of the United States is authorized to protect landmarks, structures, and objects with historic or scientific interest by claiming them as National Monuments. The Antiquities Act of 1906 only applies to federally recognized Tribal Nations. In 1966, the National Historic Preservation Act allowed Tribes to implement their own preservation program (Ferguson 1996, 67). This was followed up by the Archaeology Resources and Protection Act of 1979 that requires consent of Indian Tribes to be obtained before the federal government issues permits for excavation and removal of materials from Tribal lands (Ferguson 1996, 66). As a response, the Native American Graves Protection and Repatriation Act of 1990 has two goals: to give Native Americans property rights to grave goods and cultural patrimony and to repatriate human remains from federal and Native lands (Ferguson 1996, 66).

These laws were a positive step towards equitable research methods for archaeologists and Tribal members; however, federally recognized Tribes still receive an advantage over state recognized Tribes. There are laws that protect and advocate for federally recognized Native land and people, while state recognized Tribes must constantly fight the government and state officials to combat land encroachment. The Society of American Archaeologists (SAA) urged archaeologists to work with non-federally recognized Tribes in 1995 because the SAA were aware of the injustice state recognized Tribes face (Ferguson 1996, 68). With all of these changes to archaeology within the past fifty years, newer approaches to the discipline emerged to promote more equitable methods with the Native Tribes. Collaborative archaeology, where both non-Natives and Native members can actively learn about research methods and Native history, redefines who narrates the story of Native people in the United States (Ismail and Cazden 2005).

The University of Massachusetts, Boston Eastern Pequot Archaeology Field School Since 2003, Professor Stephen Silliman has collaborated with the Eastern Pequots through an archaeology program. This program has had 13 Field School seasons with each year focusing 
on various parts of the Eastern Pequots' land reservation. Over 13 Field School seasons, there have been approximately 30 Tribal interns and 130 non-Native participants involved in the program's mission (Table 3). Out of these numbers, five enrolled students have been Native American (Personal Communication with S. Silliman: December 17, 2018). This course has two objectives: 1) "it teaches students the basics of archaeological field research methods such as mapping, excavating, subsurface surveying, and artifact analysis" (Silliman 2008, 69); 2) it creates close connections between undergraduate and graduate students and the Eastern Pequot community. The Eastern Pequots benefit from this program because they have access to resources through "lowercost historic preservation efforts, practical archaeological training for tribal members, and Native oversight of research" (Silliman 2008, 69). Additionally, this work is unique in nature because it is assisting a state recognized Tribal Nation - that is next door to two large federally recognized Tribes - with their own summer archaeology program. Assessed by Giovanna Vitelli (2011), Native American persistence in colonial New England can be challenging for both Western and Native researchers. Vitelli believes Silliman finds a balance between having the academic authority to write about Native American history and learning about it directly from the Native community themselves (Vitelli 2011, 185). Silliman's close relationships with Tribal Nations from both the West and East coasts bridges the power gap between the academic and the descendant communities.

Table 3. Overall Demographics of the Eastern Pequot Archaeological Field School Participants from 2003-2018

*Native American Students 5

Non-Native American Students 130

Tribal Interns

Total 147

*2 Eastern Pequots, 1 Narragansett, 1 Navajo, and 1 Akimel O'odham
Throughout 2002, during their federal recognition application process, the Eastern Pequot Tribal Council was interested in beginning cultural and historic preservation on their reservation to strengthen the evidence that validated their ancestral existence. They wanted an archaeological survey of their reservation to determine the kinds of sites present on their land reservation and the necessary action to preserve them (Silliman and Sebastian Dring 2008). The goal aids the Eastern Pequots' desires to document any material culture of their history that supplements what was already known through oral traditions and written documentations (Silliman 2008). The archaeological program took place during the summers of 2003 and 2004 during the same time as the Eastern Pequots' petition. Even though their recognition was rescinded from them, the Eastern Pequots continued the program.

My personal relationship with the Eastern Pequots allowed me to gain deep insights into their experiences with federal recognition. Our relationship began in 2016 when we collaborated to make a community garden for the Tribal Nation. Additionally, from 2016 to 2017, I volunteered to assist the Eastern Pequots during any social event they hosted such as the annual Pequot Warrior Race and tag sale. During this time, my undergraduate institution, Connecticut College, aimed to increase collaboration between nearby Native American Tribes and the multicultural center on campus. I invited the Eastern Pequots to share their experiences and history with the student population at multiple educational events. Some of these gatherings included celebrating Indigenous People's Day, teaching a talk called We are Still Here, and promoting botanical walks on the reservation. In the summer of 2018, I participated in UMass, Boston's Eastern Pequot Archaeological Field School program with Professor Stephen Silliman. This program allowed me to strengthen my bond with the Tribal Nations and conduct my independent research alongside the Pequot Tribe.

For the duration of the Field School, Eastern Pequot Tribal Council members critically analyze archaeology methods and adjust them to Native traditions. The modified methods are carried out by the Tribal Interns who oversee 
the daily operations of the program. Their responsibilities include the following: smudging newcomers with a bundle of tobacco and sage to cleanse the guests of any negative energy when entering the reservation, blessing any of the shovel test pits and excavation units where artifacts were taken from, and providing any historic or geographic information on the Tribe.

On the Eastern Pequots' 225-acre land reservation, Tribal Interns act as a bridge between the professionals/academics and the public in order to better interact with members of the Tribal Nation. The Tribal Interns are chosen by Tribal Council and recommended to Professor Silliman to hire during the Field School season (Personal communication: S. Silliman July 15, 2018). Silliman extends the Field School resources, such as academic discussions and full immersion into archaeological methods, to the participating Tribal Interns. This free opportunity for the Tribal Interns gives them academic credit through the university which can be applied to an archaeology degree (Silliman 2008). Additionally, this collaborative effort "sets the context for community members to take over their own heritage management and research in the future" (Silliman 2008, 74). The phenomenon changes who has the authority to tell Native history to a Native community in order to "[ensure] that [the] academic discourse does not alienate descendent communities" (Silliman 2008, 74).

Every field season has a different Tribal Intern, but many past Tribal Interns return to participate in the program. During my time in this program in 2018, Natasha "Nikki" Gambrell and Erica Blocker were the two Tribal Interns. Nikki, a Tribal Council member at the age of 26, has been a part of the program since she was 16 years old. At that young age, Nikki dug with the other students while other Tribal members, such as Bobby or Royal "Two Hawks" Cook, blessed the excavated holes and guided the groups throughout the reservation. Since 2008, Nikki has only missed one Field School season in 2015 where she worked for the Mohegan Archaeological Field School as their Tribal Intern. Additionally, the summer of 2018 was Erica's first time in the Field School. As a 20-year -old Eastern Pequot, Erica saw this as an opportunity to reconnect with her cultural heritage. From the moment the program started, Erica quickly realized how her family was expanding as she met more and more of her Native cousins from the Tribe. Throughout the field season, Nikki assisted Erica in learning more about the cultural significance of the reservation and passed down oral traditions such as dances used at their annual PowWow.

\section{The Field School's Daily Operations}

\section{Orientation}

On the first day of the program, Silliman reminded the students of the purpose of the program and clearly stated that "this program aims to decolonialize archaeology by looking at the Eastern Pequots' material culture" (Personal communication with S. Silliman: July 1, 2018). Later that day, Silliman invited members of the Eastern Pequot to join the orientation. Those who came were members of the Tribal Council and Tribal Elders. For me, the orientation was a reunion as I had not seen many of the Tribal members for months. There was a lot of high energy, laughter, smiles, and hugs when Silliman saw each Tribal member, thus showing how much trust Silliman has gained from Tribal Council over the years.

After introducing ourselves, the Tribal members shared some information about themselves, what their role is in the Tribe, and their opinions about the Field School. Overall, the Tribal members shared positive thoughts of the program and stated how excited they were for the students to be a part of the Field School. During this time, Erica Blocker mentioned that she was also Eastern Pequot and interested in learning more about her culture and her extended family. One of the Tribal elders, Aunt Mary, asked Blocker how she was related to the Eastern Pequot Tribe. Erica explained her ancestral line that began with Phoebe Ester Sebastian Smith. Aunt Mary quickly exclaimed that they were related. In this moment, the Field School reunited a member of the Tribe who has been so disconnected from her extended family and reconnected them to her roots. The bond these two members created through this program intensified their identity as a whole and strengthened their ability to be part of a sovereign Nation. Beyond the educational component of the Field School, the program also creates a centralized location and 
group for the Eastern Pequot members to come together as one community.

\section{In-class Assignments}

Before we began digging in the field, students were expected to understand and discuss the Eastern Pequots' history in various medias; this included readings discussing collaborative archaeology programs, analyzing the power relations between the Connecticut state government and the Eastern Pequots, watching a documentary on the Pequot Massacre of 1636 called 10 Days that Unexpectedly Changed America by the History Channel, and visiting the Mashantucket Pequot Museum and Research Center to watch the film The Witness. Both of these films gave an overview of the Massacre, but from different perspectives. In fact, during the student led discussion of the History Channel's documentary, students realized how the Eastern Pequot were not mentioned, but their federally recognized cousins were. Additionally, students noticed how the documentary failed to acknowledge colonists' racist acts during the 1600 s. During the visit to the Mashantucket Pequot Museum and Research Center, students were immersed in the ethnographic museum which showed how the Pequots prior to the Massacre. Additionally, students viewed The Witness, a live-action film retelling of the Pequot Massacre from the Native Americans' perspective, to gain a deeper understanding of Native American relations between each Tribes and the colonists leading up to the Massacre. Due to the viewing of these two very different documentaries, the Field School students developed a basic understanding of Eastern Pequot history in southeastern Connecticut.

While in the field site, all participants were responsible for recording what artifacts were found; these artifacts were then placed in documented bags. At the end of each day, Silliman's graduate teacher's assistant would track the artifact bags on a log sheet which documented the number of bags that contained various findings. This practice had a mutual benefit for the Field School and the Tribal Nation as it helped the Field School keep track of any artifacts while informing the Tribal Nation of which items are being removed from the land. After the log sheet was filled out, the
Tribal Intern would sign it to acknowledge that the artifacts would be removed from the land. Lastly, the Tribal Intern, specifically Nikki as she had ample experience in the program, blessed each excavated hole with a Native prayer thanking the Creator. The Tribal Intern then sprinkled tobacco in the shape of a circle over the hole. As the program continued and more artifacts were found, the whole Field School tried to hypothesize the house foundation's function. By laying out the artifacts on a makeshift map, students were encouraged to analyze any patterns they observed in the artifacts. Since this was one of the largest digging sites throughout the Field School seasons, there are still many unanswered questions about the house foundation and its purpose.

The Legacy of the Eastern Pequot Archaeology Field School with University of Massachusetts, Boston

The Field School generates ample resources and knowledge on the Eastern Pequots for Natives, non-Native students and politicians to witness and build new understandings of Native Americans during the US' 1600-1800's colonial history. Over the 13 Field School seasons, over 99,000 artifacts were collected and documented. In the summer of 2018 season alone, two arrows heads, a squibnocket, scissors, a coin dating back to the early 1800s, and a utensil set were just a few of the artifacts found during the excavation. All of these items suggest that the Eastern Pequot members did not culturally assimilate to satisfy European colonizers during the 1800s. Instead, these artifacts show that the Eastern Pequots survived European colonization by adapting to the European lifestyle while still maintaining their Native traditions. These artifacts dismantle the dominant binary discourse that Native Americans on the east coast either 1) assimilated into European culture to survive or 2) dwindled as a consequence of not assimilating to the European lifestyle (Silliman 2012).

Additionally, the longevity of the Field School serves to disassemble the misconception of time during early colonial periods. One of the major fallacies Stephen Silliman finds in Indigenous archeology is the "conundrum of 
[the] temporal scale" through the concepts of "longue durée" and "short purée" (Silliman $2012,113)$. The longue durée concept originates from the French philosopher Henri Bergson, who developed it as a theory of time and consciousness. This perspective of time summarizes major events but fails to include the mundane activities that can lead up to the events. It is common to misinterpret Indigenous practices within the colonial world in this way, by situating them into either a short or longterm cultural history (Silliman 2012, 113). This binary is limiting because archaeologists tend to choose one and not the other to represent Indigenous narratives (Silliman 2012). One of its limitations is that it "downplay[s] the impact of colonialism ... in light of long-term Indigenous histories that span centuries ... before the arrival of the European colonists" (Silliman 2012, 114). Silliman critiques scholars who attempt to investigate a significant number of events within a short period of time (Silliman $2012,120)$. This method creates a false sense of longue durée because it "obscures the shorterterm strategies, decisions, and process that link past and present that give long durations of cultural patterns their actual power" (Silliman 2012, 121).

In contrast, the short purée perspective is a general representation of Indigenous experiences that blurs the lines between each distinct tribal nation and blends them down into a single identity. Like a food processor creating a homogeneous mush, this perspective "fundamentally altered [Indigenous cultures] by the presence of European colonists and colonies, frequently to the point of becoming unrecognizable in terms of their previous cultural ways" (Silliman 2012, 114). Clearly, this method is problematic because it misrepresents all Native American tribes and strips them of their cultural power and historic importance. Furthermore, Silliman critiques archeologists who focus on the first colonial interactions despite there being more archaeological material records on the later periods (Silliman 2012, 145). He argues against describing the time period through "first encounters" and/or "early contact periods" (Silliman 2012, 115). Silliman states that segmenting time through this lens and focusing on only the first colonial interactions "[emphasizes] these early periods [and] sever[s] present Indigenous communities from their pasts and their abilities to exert claims on them" (Silliman 2012, 115). This pattern is detrimental to Native communities because this knowledge is commonly taught in many middle schools across the United States, so the Native American discourse has been rewritten and accepted in a generalized fashion that should be contested.

For many of the Tribal Interns, the Field School encourages land-based education and connects them back to their land and relatives (Personal communication with N. Gambrell: July 15,2018 ) (Figure 4). For example, Nikki does not dig with gloves. She states that digging with her bare hands establishes the intimate relationship to Mother Earth and her land reservation which connects to her ancestors (Personal communication with N. Gambrell: July 15, 2018). Additionally, the Field School allows Tribal Interns to carry on the legacy of Eastern Pequot participants who have passed away. For example, Ralph Sebastian, a Tribal Elder, was deeply involved in the beginning of the Field School's history and shared Eastern Pequot history with the Native and non-Native students. After his passing, younger Tribal Interns commemorate his contributions to the Tribal Nation and the Field School by embodying the knowledge of the reservation and their shared history (Personal communication with N. Gambrell: December 17, 2018). Even for Eastern Pequot members who only volunteered to dig for a short period of time, this program can still connect them to their ancestors' past. One individual who was adopted back into the Tribal Nation as a young adult participated in the Field School for the first time this year in 2018. He stated that digging through the excavation units and sifting through the dirt was like "opening a time capsule" to his Native ancestors (Personal Communication with Eastern Pequot Tribal member: September 15, 2018). As a Native adopted child, this work is crucial because it provides tangible artifacts that refute American discourses on Native Americans while providing insights of how the Eastern Pequot survived during early colonization in the United States.

The Field School provides an opportunity to educate politicians about who the Eastern 
Pequots are, both historically and contemporarily, and how they live after the state government's inequitable actions to rescind their federal acknowledgement. During the Field School season, Silliman and the Tribal Council invited Connecticut's selectman and politicians to witness the digs in action. One Tribal member stated that is it easy for Connecticut's government to make unjust policies towards the Eastern Pequots because the people in positions of power do not know of the Tribal Nation's history (Personal Communication with Eastern Pequot Tribal member: September 15, 2018). Inviting politicians to the Eastern Pequots' land reservation to interact with the Natives builds bridges between the communities that have been unstable for many years.

Due to the house foundation's close proximity to the PowWow circle, it was an accessible location to invite many Tribal members and outsiders to witness the Field School in person. For example, local townspeople visited the site to simultaneously see what the students were digging and to learn from an archaeologist the impacts of this program. During these visits, the outsiders were accompanied by a Tribal member, so it bridged these two groups together. Additionally, tribal members and visitors visited the house foundation during the Eastern Pequots' annual PowWow. Silliman invited Tribal members to the house foundation to showcase some of the areas we were working in to maintain transparency with the whole Tribe. The Field School provided many answers about the dwellings cross the reservation. There are many stone walls and house foundations scattered throughout the land; however, the Tribal members did not understand why they were there, how they were used, or who lived in these houses. Each Field School season investigated each structure that provides some

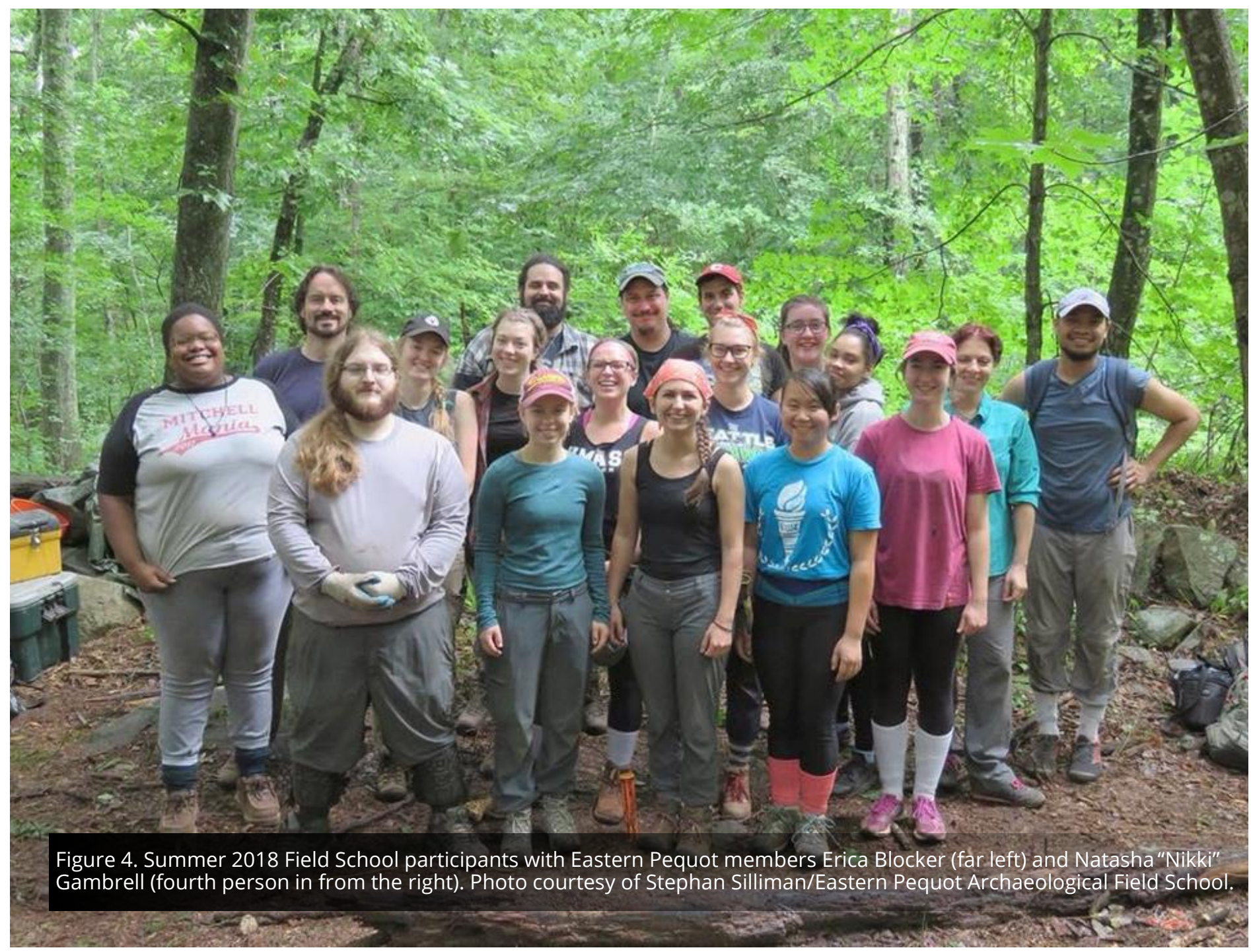


historic context for the Tribal Nation. This helped the Tribal members gain a better understanding of how their ancestors used the reservation while dismantling the common discourse that Native Americans assimilated into European culture. Joanne, a Tribal member who visits each Field season stated "that the land ... could talk because you can hear the ancestors talking to you, 'This is who we were."'

\section{Conclusion}

The vital information found throughout each excavation plays a role in legitimizing the Eastern Pequots' identity. When the United States government rescinded the Eastern Pequots' federal recognition, the government also robbed the Tribal Nation of their agency to legitimize their own Native history (Starn 2011). The result of the government granting and then rejecting the Eastern Pequots' recognition status led to uncertainty and imbalance within the Tribal Nation. Eastern Pequot members argue that the government, specifically Connecticut Senator Richard Blumenthal, does not believe that Eastern Pequots exist anymore (Personal communication with N. Gambrell and V. Gambrell: July 15, 2018). To combat this erasure, the Field School provides tangible items from the past which grounds the Tribal members to their reservation that has been established for hundreds of years. Items such as arrowheads, musket bullets, and scissors show that the Eastern Pequots' ancestors lived with their European colonizers from the 17th to the 19th centuries as their Native presence was enough to resist colonization. Over 99,000 artifacts found throughout the 15 Field School seasons dismantle the common misconception of how Native Americans lived during the beginning of the United States' history and redefines modern beliefs about how Natives survived European colonization. The Field School transforms the brief binary description of Native history into a more complicated and dynamic story that elaborates on Native struggle, survival and resistance. Through their gradual collaborative academic research, students produced honors theses and have presented this information to larger audiences to increase the number of research publications on the Eastern Pequots' history and experience. This research beneficially serves the Eastern
Pequots because the rising number of publications completed with a university authenticates their history within Western pedagogy. The Field School uncovers artifacts that prove the Eastern Pequots' ancestors lived, survived and thrived on the same land that European colonizers and current Tribal members walk on today. For many members, their research reconnects them to their past and encourages them to continue to learn more about their heritage (Personal communication with E. Blocker: July 6, 2018). Lastly, these artifacts and the ample knowledge that comes with them can be used towards the "BIA, US Department of the Interior in [the Eastern Pequot] petition for federal acknowledgement" (Personal communication with K. Sebastian: August 3, 2018).

The Eastern Pequot Archaeological Field School provides a unique opportunity for Eastern Pequot members to determine how they want to represent themselves and learn with archaeologists and non-Natives in ways that can ultimately decolonize Western pedagogy, anthropology and archeology. In both the archaeology Field School and in my anthropological research, the Eastern Pequot members had full participation in the outcomes of the research - highlighting their voices and how they want to represent themselves. It switches the power dynamics between the elitist academic researchers and the ones being researched. In return, one of the many benefits of this program is that it gives students the firsthand exposure to the resilience Eastern Pequot members exhibit every day. Through this collaborative program, the Field School helps shed light on equitable education programs that aim to work with under resourced communities due to the lack of federal recognition while breaking down many negative stereotypes that Native communities have of archaeologists. By educating members of the Tribal Nation and non-Natives, the Field School combats the cultural erasure colonizers implement because it brings awareness of Native history and modern presence. A collaborative archaeology program such as this can encourage more disciplines to pursue equitable research with other minority groups in hopes to give power back to minority groups. 


\section{Acknowledgements}

Thank you to the Eastern Pequot Tribal Nation for welcoming me into the Tribe and allowing me to listen and learn from each of you over the past three years. Thank you to Professor Ronald Flores, Professor Stephen Silliman, and Professor Natalie Avalos for exposing me to the oppression and discrimination Native Americans face. Thank you to Professor Joyce Bennett for your guidance and patience to teach me what is equitable research in a field of study where minorities usually remain marginalized. This paper is in loving memory of Bobby Sebastian and Ralph Sebastian who both passed away; both men played a large role in the Field School program. 


\section{References}

Bogado, Aura. 2014. "For Some Native Tribes, Federal Recognition Remains Out of Reach." Colorlines website, October 15. Accessed [May 14, 2018]. https://www.colorlines.com/articles/some-nativetribes-federal-recognition-remains-out-reach

Charles, James N. "Involvement of Native Americans in Cultural Resources Programs." 2007. Plains Anthropologists. 44, 170 (1999): 25-34. Constitution of the Eastern Pequot Tribal Nation. May 18. Accessed [November 18, 2018]. http:// www.easternpequottribalnation.com/wp-content/ uploads/2017/03/Eptn-Constitution-02-13-2017_14-29-15-9411.pdf

Ferguson, T. J. 1996. "Native Americans and the Practice of Archaeology." Annual Review of Anthropology. 25, (1): 66-79.

Field, Les W. 1999. "Complicities and Collaborations: Anthropologists and 'Unacknowledged Tribes' of California." Current Anthropology. 40, (2):193-209.

Gaudry, Adam and Lorenz, Danielle. 2018. "Indigenization as inclusion, reconciliation, and decolonization: navigating the different visions for indigenizing the Canadian Academy." AlterNative: An International Journal of Indigenous Peoples. 14, (3):218-227.

Greymorning, Neyooxet. 2014. "Mohawk Interruptus: Political Life across the Borders of Settler States by Audra Simpson." American Anthropologist 117, (2): 444-445.

Groark, Virginia. 2002. "Pequot Recognition is Only the First Step." The New York Times website, June 30. Accessed [October 10, 2018]. https://www.nytimes.com/2002/06/30/nyregion/pequotrecognition-is-only-the-first-step.html

Hardin, Peter. 2015. “Indian Paper Genocide: Racial Supremacist Walter Plecker. Walter Pleck: Master of Documentary Genocide." American Indian Adoptees website, February 3. Accessed [October 21, 2018]. http://blog.americanindianadoptees.com/ search?q=paper+genocide

Hayness, John, Ludlow, Roger, Hopkins, Edward, Mark of Miantonomo, and Mark of Poquiam. 1638. Treaty of Hartford. Colony of Connecticut. From Yale Indian Papers Project. Accessed [September 14, 2018] https://yipp.yale.edu/annotatedtranscription/digcoll2389 
Ismail, S. Masturah, and Cazden, Courtney. 2015. "Struggles for Indigenous Education and Self-Determination: Culture, Context, and Collaboration." Anthropology and Education Quarterly. 36, (1): 88-92.

Lorde, Audre. 1984. "The Master's Tools Will Never Dismantle the Master's House." Sister Outsider: Essays and Speeches. Ed. Berkeley, CA: Crossing Press. 110- 114. 2007.

Manuelito, Kathryn. 2005. "The Role of Education in American Indian Self-Determination: Lessons from the Ramah Navajo Community School." Anthropology and Education Quarterly. 36, (1): 73-87.

McFadden, Robert. 2000. "Indian Bureau recommends Federal Recognition for Two Pequot Tribes in Connecticut." The New York Times website, March 25. Accessed [May 24, 2018]. https:// www.nytimes.com/2000/03/25/nyregion/indian-bureaurecommends-federal-recognition-for-two-pequot-tribesconnecticut.html

Radelat, Ana. 2015. “U.S. denies CT tribes chance at federal recognition." The CT Mirror. June 29. Accessed [May 20, 2018]. https://ctmirror.org/2015/06/29/u-s-denies-ct-tribes-anotherchance-at-federal-recognition

Silliman, Stephen W. and Katherine H. Sebastian Dring. 2008. "Working on Pasts for Futures: Eastern Pequot Field School Archaeology in Connecticut." In Collaborating at the Trowel's Edge: Teaching and Learning in Indigenous Archaeology, edited by S. Silliman, 67-87.

Silliman, Stephen W. 2012. "Between the Longue Durée and the Short Purée." In Decolonizing Indigenous Histories: Exploring PreHistoric/Colonial Transitions in Archaeology, edited by M. Oland, S.M. Hart, and L. Frink. 113-131.

Simpson, Audra. 2014. Mohawk Interruptus: Political Life Across the Borders of Settler States. Durham, NC: Duke University Press.

Starn, Orin. 2011. "Here comes the anthropologists (again): The strange marriage of Anthropology and Native America." Cultural Anthropology. 26, (2): 179-204.

United States. Department of Interior. Bureau of Indian Affairs. 2016. Connecticut General Statutes 47-59a - Connecticut Indians; citizenship, civil rights, land rights. Accessed [November 18, 2018].https://www.lawserver.com/law/state/connecticut/ct-laws/ connecticut_statutes_47-59a 
Vitelli, Giovanna. 2011. "Change and Continuity, Practice and Memory: A Response to Stephen Silliman." American Antiquity 76, (1): 177-189.

Wildcat, Matthew, McDonald, Mandee, Irlbacher-Fox, Stephanie, and Coulthard, Glen. 2014. "Learning from the Land: Indigenous land based pedagogy and decolonization." Decolonization: Indigeneity, Education \& Society. 3(3):I-XV.

\section{Personal Communications}

Blocker, Erica. 2018. Personal communication with LH Nguyễn.

Eastern Pequot member. 2018. Personal communication with LH Nguyễn.

Flores, Ronald. 2017. Personal communication with LH Nguyễn.

Gambrell, Natasha "Nikki." 2018. Personal communication with LH Nguyễn.

Gambrell, Valeria. 2018. Personal communication with LH Nguyễn.

Mashantucket Pequot member. 2017. Personal communication with LH Nguyễn.

Sebastian, Kathy. 2018. Personal communication with LH Nguyễn.

Silliman, Stephen. 2017. Personal communication with LH Nguyễn.

Silliman, Stephen. 2018. Personal communication with LH Nguyễn.

Silva, Joanne. 2018. Personal communication with LH Nguyễn.

\section{(ब) $(\Theta \Theta$}

This work is licensed under a Creative Commons

Attribution-NonCommercialNoDerivatives

4.0 International License. 